\title{
Health, work, and development: agribusiness and accidents in a state in the Brazilian Amazon region
}

\author{
Saúde, trabalho e desenvolvimento: agronegócios e \\ acidentes em um estado da região Amazônica
}

\author{
Darléia Cristina Gross Andrade Nascimento1,2, Marta Gislene Pignatti ${ }^{3}$, \\ Luis Henrique da Costa Leão ${ }^{3}$, Ângela Lúcia Piccini de Oliveira ${ }^{1}$, \\ Ageo Mário Cândido da Silva ${ }^{1,3}$
}

\begin{abstract}
Introduction: Mato Grosso is one of the Brazilian states with the highest agribusiness growth, which is accompanied by deforestation and an increase in occupational injuries. Objective: To assess some factors associated with agribusiness-related severe occupational injuries in Mato Grosso. Method: Occupational injury notifications were provided by the System of Information of Notifiable Injuries (SINAN). The production sectors, considered the dependent variables, were classified as forestry/wood industry, animal husbandry, and plant husbandry. Some sociodemographic, care, and type of injury-related variables were selected and considered the independent variables. We conducted a spatial analysis of the density of occupational injury. The associations were identified by calculating the proportion ratio (PR) by the chi-square test and considered significant when $p$-value $<0.05$. Results and conclusion: The highest rates of severe occupational injuries occurred in municipalities with intense plant and animal husbandry, and forestry/wood industry activities. In plant husbandry severe occupational injuries were more common in men, adults, non-whites, illiterates, and rural areas. However, in animal husbandry and forestry/wood industry, severe occupational injuries were more common in adults, and full recoveries were less frequent.
\end{abstract}

Keywords: occupational injuries; Amazon region; agribusiness.

\section{Resumo}

Introdução: O Mato Grosso é um dos estados brasileiros com maior crescimento do agronegócio, acompanhado pelo desmatamento e pelo aumento da ocorrência de acidentes de trabalho. Objetivo: Avaliar alguns fatores associados aos acidentes graves na agropecuária em Mato Grosso. Método: As notificações de acidentes foram fornecidas pelo Sistema de Informação de Agravos de Notificação (SINAN). Os setores produtivos foram classificados em produção de madeira, pecuária e agricultura, e considerados como variáveis dependentes. Algumas variáveis sociodemográficas, de atendimento e de tipificação do acidente foram selecionadas e consideradas como independente. Realizou-se uma análise espacial de densidade das taxas de acidentes de trabalho. Identificaram-se as associações por meio do cálculo da razão de proporções (RP) pelo teste do qui-quadrado, considerando-se como resultados estatisticamente significantes aqueles com p-valor <0,05. Resultados e conclusão: As maiores taxas de acidentes de trabalho graves ocorreram nos municípios de intensas atividades da agricultura, pecuária e exploração de madeira. Na agricultura, houve maiores proporções de acidentes graves entre homens, adultos, não brancos, analfabetos e na zona rural. Em relação à pecuária e à madeira, essa proporção foi maior entre os trabalhadores adultos e com menores taxas de cura.

Palavras-chave: acidentes de trabalho; Região Amazônica; agronegócio.

\footnotetext{
${ }^{1}$ Centro de Referência em Saúde do Trabalhador (CEREST), Secretaria Estadual de Saúde (SES) - Cuiabá (MT), Brazil.

${ }^{2}$ School of Physiotherapy, Universidade de Cuiabá (UNIC) - Cuiabá (MT), Brazil.

${ }^{3}$ Universidade Federal de Mato Grosso (UFMT) - Cuiabá (MT), Brazil.

Study carried out at Universidade Federal do Mato Grosso (UFMT) - Cuiabá (MT), Brazil.

Correspondence: Darléia Cristina Gross Andrade Nascimento - Rua 3, 235 - Boa Esperança - CEP: 78086-375 - Cuiabá (MT), Brazil - Email: darleiagross@gmail.com

Financial support: none.

Conflict of interests: nothing to declare.
} 


\section{INTRODUCTION}

Mato Grosso has been pointed out as one of the federated states with the highest gross domestic product (GDP) growth in the last years mainly due to agribusiness. In 2012 its growth of $4.6 \%$ was four times greater than the Brazilian GDP growth ${ }^{1}$.

Known as the "Brazilian breadbasket", its production profile consists mainly of agribusiness-related production chains, especially soybean, sugarcane, cotton, and corn crops, in addition to animal husbandry, especially cattle, and forestry/wood industry ${ }^{3}$.

Agribusiness - husbandry and forestry/wood industry - is responsible for $70 \%$ of the state's economy, and this economic growth has been accompanied by the destruction of ecosystems, deforestation, higher domestic migration and immigration, concentration of income and land property, urbanization, more violence against indigenous nations and traditional people in urban and rural areas, overexploitation of poorer and more vulnerable workers, and indiscriminate pesticide use, among others ${ }^{4,5}$.

This economic development model, unfair and unequal, is the main determinant of environmental degradation and human health deterioration ${ }^{6,7}$. This is because the agribusiness production chains in the state's territory are complex social, technical, and environmental systems that expose the environment and the population, especially workers, to all kinds of risks and hazards in all stages of production. That's the reason why Mato Grosso began to stand out in the Brazilian statistics of health problems, especially occupational health problems ${ }^{8}$, to a point that the incidence of occupational injuries nearly doubled between 1998 and $2008^{9}$.

Within the set of social, environmental, cultural, and sanitary repercussions of these production chains, the occurrence of occupational injuries represents one of the most severe and persistent public health problems in the Amazon region. Occupational injury-related morbidity and mortality is a priority issue for research-based interventions in this region, especially regarding severe occupational injuries, as these events result in physical or functional mutilations with disastrous consequences ${ }^{10}$.

The health sector, through Reference Worker's Health Centers, is trying to improve the occupational injuries records and notification in the state's regions, especially considering that the populations in this part of the Amazon bear the effects of this model of development, which increases the rates of mortality, severe diseases, and severe injuries. Hence, considering that the morbidity and mortality patterns reflect the adopted production models, this article aimed to characterize the severe occupational injuries notified in the state by sociodemographic characteristics, type of injury and care, and their association with the husbandry and forestry/wood industry sectors of Mato Grosso.

\section{METHODS}

Data on severe occupational injuries were obtained from the System of Information of Notifiable Injuries - SINAN - which records notifiable diseases and injuries ${ }^{11}$. All severe occupational injuries notified between 2010 and 2012 in the state of Mato Grosso with a National Classification of Economic Activities (CNAE) number were selected ${ }^{12}$.

Batalha ${ }^{13}$ discriminates the agribusiness production chains into three major groups: production of raw materials (e.g., planting of crops and trees, logging, harvest and storage of grains and similar products, animal husbandry, etc.), processing (e.g., wood and grains processing, slaughter of poultry, small animals, and cattle, fish farming, etc.), and merchandizing. Following this logic, the economic activities in the notification forms were reclassified by production sector: plant or animal husbandry, and forestry/wood industry (Chart 1).

The other notifications with CNAE codes that did not belong to any of these classes were grouped and classified as other production sectors. We included all notifications that contained the data for all the study variables, resulting in a database with 1,497 severe occupational injury notifications.

The study's sociodemographic variables were gender (male/female), age group, originally classified as aged less than 18 years, aged 18 to 59 years, and aged 60 years or more, and later recategorized as aged less than 18 years and aged 18 years or more; skin color, initially categorized as white, black, brown, yellow, and other, and later recategorized as white and other. Regarding the age group, this recategorization was given in an attempt to observe the serious accidents regarding child labor. Skin color was reclassified based on the different migratory patterns where the white came, mostly from southern Brazil and others, are either indigenous or origin of the north and northeast regions. Education level was categorized as illiterate and literate. This categorization was due to the high proportion of people with low education level, not allowing greater stratification. Residence zone was categorized as rural and urban zone. Work-related variables were type of injury (occupational injury or commuting accident), it is understanding that the hospital care were the most serious, and type of care (inpatient, outpatient, and both, and later recategorized as inpatient (included exclusive inpatient care or a mixture of inpatient and outpatient care) and outpatient (exclusive outpatient care); and outcome, originally categorized as full recovery, temporary or partial disability, permanent or total disability, and death. This variable also was recategorized as full recovery and severe outcomes, where healing was the outcome of lesser severity.

Descriptive and bivariate analyses were conducted. The descriptive analysis initially consisted of a spatial analysis of the graph showing number of accidents per 10,000 economically 
Chart 1. CNAE classes by agribusiness production

\begin{tabular}{|c|c|}
\hline Agribusiness Production & CNAE CLASSES \\
\hline Plant husbandry & $\begin{array}{l}\text { 0161-9 - activities of plant husbandry-related services; } \\
0111-2 \text { - cultivation of cereals for grains; } \\
0112-0 \text { - cultivation of upland cotton; } \\
0113-0 \text { - cultivation of sugarcane; } \\
0115-5 \text { - cultivation of soybean; } \\
119-8 \text { - cultivation of other temporary crops; } \\
1711-6 \text { - cotton processing; } \\
0115-5 \text { - cultivation of soybeans; } \\
0119-8 \text { - cultivation of other temporary products. }\end{array}$ \\
\hline Cattle farming & $\begin{array}{l}1511 \text { - cattle slaughter and preparation of meat products; } \\
1512-1 \text { - slaughter of poultry and other small animals and preparation of meat products; } \\
0162-7 \text { - activities of animal husbandry-related services - except for veterinary activities; } \\
0141-4 \text { - cattle farming; } \\
0145-7 \text { - poultry farming; } \\
0146-5 \text { - farming of other animals; } \\
0142-2 \text { - farming of other large animals; } \\
0143-0 \text { - sheep farming; } \\
0144-9 \text { - pig farming. }\end{array}$ \\
\hline Forestry/wood industry & $\begin{array}{l}\text { 2010-9 - headrig sawing; } \\
\text { 0212-7 - forestry/wood industry; } \\
\text { 2021-4 - manufacturing of laminated wood and plywood; } \\
\text { 2022-2 - manufacturing of wood miter, prefabricated timber houses, timber structures and } \\
\text { carpentry articles; } \\
0213-5 \text { - activities of forestry/wood industry-related services. }\end{array}$ \\
\hline
\end{tabular}

active inhabitants ${ }^{14}$. In bivariate analysis, the sociodemographic, injury-related, and care-related variables were classified as independent, and the sectors plant husbandry (yes/no), animal husbandry (yes/no), and forestry/wood industry (yes/no), as dependent variables. Therefore, the null hypothesis is that the independent variables, including morbidity (type of care and outcome that are indicators of severity) are not associated with the productive sectors. When rejecting the null hypothesis it is assumed that these severity indicators are "in fact" associated with the productive branches analyzed.

The associations between the independent and dependent variables were identified by calculating the proportion ratios (PR) and respective $95 \%$ confidence intervals (95\%CI). The statistical significance of the association was given by the chi-square test with a $95 \%$ confidence interval by the Mantel-Haenszel method $(95 \% \mathrm{CI})$ or by the Fisher's exact test when necessary, where the non-inclusion of the unit (1.0) in the 95\%CI represents a p-value $<0.05$, that is, a statistically significant value.

The study was approved by the Research Ethics Committee of the University Hospital Júlio Muller under number 316,383. Any information that could identify the victim, such as name, was omitted from the database.

\section{RESULTS}

Most of the victims worked in plant husbandry (23.4\%), followed by animal husbandry (14.0\%), and forestry/wood industry (9.0\%). Most were males (89.4\%) aged 18 to 59 years $(94.2 \%)$, had brown skin (53.5\%), and had completed elementary school (62.0\%). Most injuries (75.5\%) occurred in urban areas; $84.9 \%$ were occupational injuries; $50.8 \%$ were treated in outpatient clinics; $66.0 \%$ resulted in partial or temporary disability; and $29.5 \%$ resulted in full recovery (Table 1 ).

Figure 1 shows the distribution of occupational injuries rate per 10,000 inhabitants in the municipalities of Mato Grosso. The image scale varies from dark gray to light gray, representing the gradient between low and high risk. The darker shades of gray, representing higher rates of severe occupational injuries, correspond to municipalities with intense plant and animal husbandry, and forestry/wood industry activities.

Table 2 shows the bivariate analysis of the sociodemographic variables by production sector. The percentage of injured males (24.8\%) working in plant husbandry was significantly higher than of injured females $(2.0 \%)(p<0.05)$. The percentages of injured males and females working in animal husbandry and forestry/wood industry did not differ.

The proportion of injured minors (aged less than 18 years) working in the plant and animal husbandry sectors was smaller than of injured adults $(\mathrm{p}<0.05)$, but the proportion of injured minors working in the forestry/wood industry sector did not differ from injured adults.

The proportions of injured whites and non-whites working in the animal husbandry and forestry/wood industry sectors were similar. However, the proportion of injured non-whites 
Table 1. Descriptive statistics of the study variables, severe occupational injuries, 2010 and 2011, Mato Grosso

\begin{tabular}{|c|c|c|}
\hline & Prevalence & $\%$ \\
\hline \multicolumn{3}{|l|}{ ECONOMIC ACTIVITIES } \\
\hline Plant husbandry & 348 & 23.4 \\
\hline Animal husbandry & 209 & 14.0 \\
\hline Forestry/wood industry & 135 & 9.0 \\
\hline Other & 805 & 53.8 \\
\hline \multicolumn{3}{|c|}{ SOCIODEMOGRAPHIC VARIABLES } \\
\hline \multicolumn{3}{|l|}{ Gender } \\
\hline Male & 1338 & 89.4 \\
\hline Female & 159 & 10.6 \\
\hline \multicolumn{3}{|l|}{ Age group } \\
\hline Less than 18 years old & 33 & 2.2 \\
\hline 18 to 59 years old & 1418 & 94.7 \\
\hline 60 years old or older & 46 & 3.1 \\
\hline \multicolumn{3}{|l|}{ Skin color } \\
\hline White & 497 & 33.2 \\
\hline Black & 154 & 10.3 \\
\hline Brown & 801 & 53.5 \\
\hline Yellow/Indigenous & 45 & 3.0 \\
\hline \multicolumn{3}{|l|}{ Education level } \\
\hline Illiterate & 55 & 3.7 \\
\hline Elementary school & 873 & 58.3 \\
\hline High school & 400 & 26.7 \\
\hline Higher education & 169 & 11.3 \\
\hline \multicolumn{3}{|c|}{ VARIABLES RELATED TO THE INJURY AND TYPE OF CARE } \\
\hline \multicolumn{3}{|l|}{ Residence zone } \\
\hline Urban zone & 1130 & 75.5 \\
\hline Rural zone & 367 & 24.5 \\
\hline \multicolumn{3}{|l|}{ Type of injury } \\
\hline Occupational & 1271 & 84.9 \\
\hline Commuting accident & 226 & 15.1 \\
\hline \multicolumn{3}{|l|}{ Care } \\
\hline Inpatient & 663 & 44.3 \\
\hline Outpatient & 760 & 50.8 \\
\hline Both & 73 & 4.9 \\
\hline \multicolumn{3}{|l|}{ Outcome } \\
\hline Full recovery & 442 & 29.5 \\
\hline Temporary or partial disability & 988 & 66.0 \\
\hline Total or permanent disability & 16 & 1.1 \\
\hline Death & 49 & 3.3 \\
\hline
\end{tabular}

working in plant husbandry was 1.44 times higher than of whites $(\mathrm{p}<0.05)$.

In plant husbandry, the proportion of injured illiterates was $56 \%$ higher than of injured individuals with any education level $(\mathrm{p}<0.05)$. This difference did not occur among animal husbandry and forestry/wood industry workers.

Table 3 shows the associations between injury related and care related variables by economic sector. The proportion of severe injuries in rural plant husbandry workers was 4.34 times higher than in urban plant husbandry workers $(\mathrm{p}<0.05)$. This difference between the proportion of injuries in urban and rural workers did not occur in the other sectors.

The proportion of occupational injuries was significantly higher than of commuting accidents in all three study sectors $(p<0.05)$. On the other hand, the proportions of inpatients and outpatients did not differ in any of the study sectors.

The proportions of severe outcomes in animal husbandry and forestry/wood industry were $88.0 \%$ and $61.0 \%$, respectively, higher than full recoveries $(\mathrm{p}<0.05)$. However, the proportions of severe outcomes and full recoveries in plant husbandry did not differ significantly.

\section{DISCUSSION}

Analysis of severe occupational injuries in Mato Grosso, regardless of the underreporting that occurs throughout the health network, indicates that agribusiness related production chains have occupational, sanitary, and social impacts. The rate 


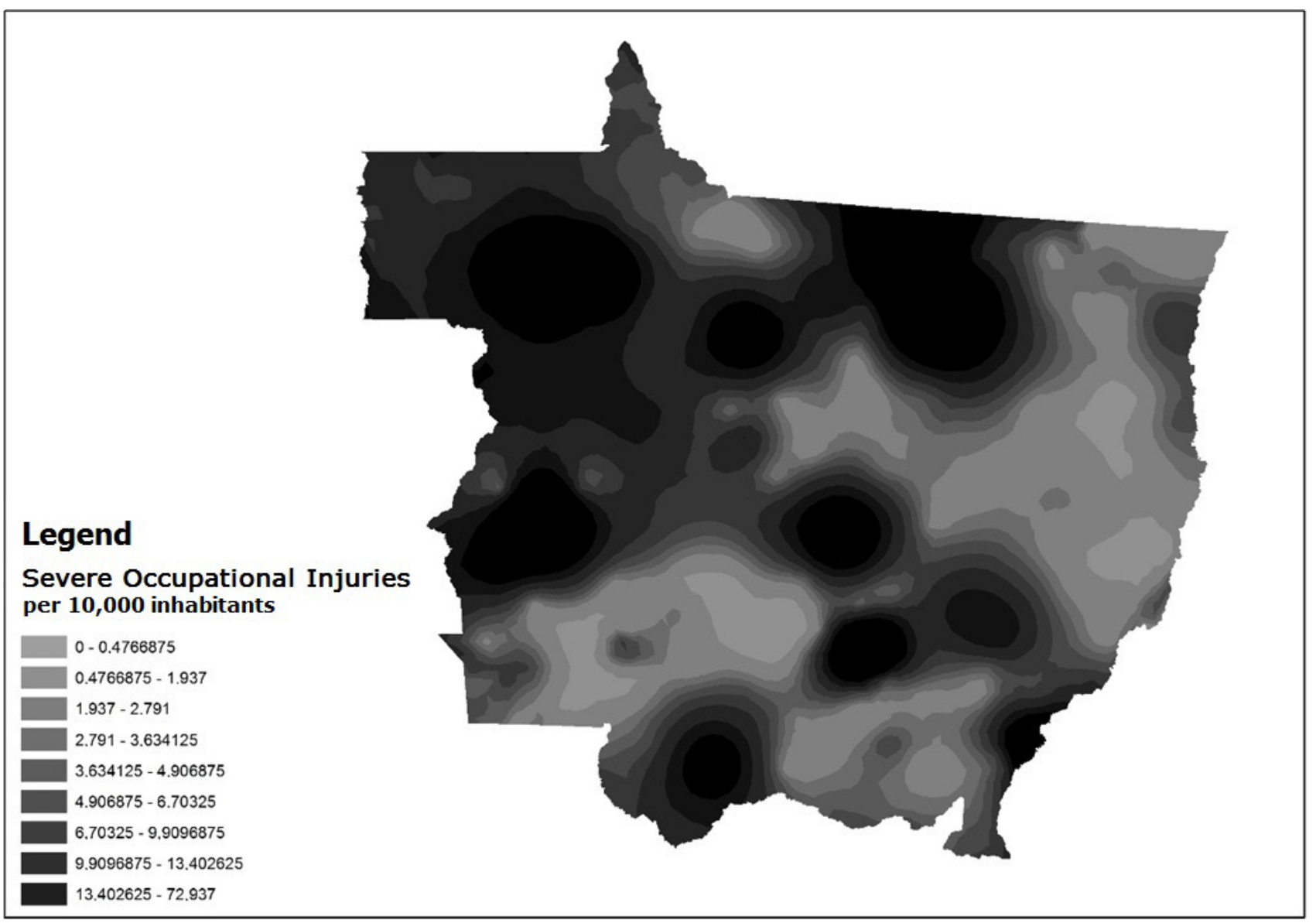

Figure 1. Distribution of the rate of severe occupational injuries per 10,000 economically active inhabitants in the state of Mato Grosso, 2010 to 2011

Table 2. Proportions of severe occupational injuries in plant husbandry, animal husbandry, and forestry/wood industry workers by sociodemographic variables, Mato Grosso, 2010 and 2011

\begin{tabular}{|c|c|c|c|c|c|c|}
\hline & $\%$ & Plant husbandry & $\%$ & Animal husbandry & & $\begin{array}{l}\text { Forestry/wood } \\
\text { industry }\end{array}$ \\
\hline \multicolumn{7}{|l|}{ Gender } \\
\hline Male & 24.8 & $16.3(5.2-51.6)$ & 14.1 & $1.06(0.70-1.64)$ & 8.0 & $1.52(0.76-3.06)$ \\
\hline Female & 2.0 & 1.00 & 13.2 & 1.00 & 5.3 & 1.00 \\
\hline \multicolumn{7}{|l|}{ Age group } \\
\hline$<18$ years & 7.6 & $0.27(0.10-0.68)$ & 1.4 & $0.29(0.09-0.92)$ & 3.4 & $0.76(0.28-2.05)$ \\
\hline 18 years or more & 23.3 & 1.00 & 4.9 & 1.00 & 4.5 & 1.00 \\
\hline \multicolumn{7}{|l|}{ Skin color } \\
\hline White & 17.3 & $0.69(0.55-0.86)$ & 13.9 & $0.99(0.76-1.30)$ & 33.6 & $1.02(0.78-1.34)$ \\
\hline Non-white & 25.0 & 1.00 & 13.8 & 1.00 & 32.9 & 1.00 \\
\hline \multicolumn{7}{|l|}{ Education level } \\
\hline Illiterate & 33.3 & $1.56(1.02-2.34)$ & 3.8 & $1.06(0.48-2.35)$ & 4.0 & $1.12(0.40-3.06)$ \\
\hline Literate & 21.3 & 1.00 & 3.6 & 1.00 & 3.6 & 1.00 \\
\hline
\end{tabular}

of injuries per municipality shows that the highest rate of notified injuries is symmetrical to the interior regions, where agribusiness production profile, especially plant husbandry, animal husbandry, and forestry/wood industry, is hegemonic. These interior regions suffer the direct effects of production chain related externalities and injuries due to the unequal social and geographic distribution of the risks and repercussions that affect mainly the poorest and most vulnerable territories ${ }^{15}$.
These effects - in the case of severe occupational injuries - are also unequally distributed between the genders. This fact may be related to the division of rural tasks: activities performed by women usually do not involve the use of more dangerous tools and equipment ${ }^{16}$.

Although the risks in the animal husbandry and forestry/wood industry sectors are greater than those in the plant husbandry sector, gender-related risks are similar since both in meat and 
Table 3. Proportions of severe occupational injuries in plant husbandry, animal husbandry, and forestry/wood industry workers by injury-related and care-related variables, Mato Grosso, 2010 and 2011

\begin{tabular}{|c|c|c|c|c|c|c|}
\hline & $\%$ & Plant husbandry & $\%$ & $\begin{array}{c}\text { Animal } \\
\text { husbandry }\end{array}$ & $\%$ & $\begin{array}{l}\text { Forestry/wood } \\
\text { industry }\end{array}$ \\
\hline \multicolumn{7}{|l|}{ Region } \\
\hline Rural zone & 56.9 & $4.34(3.63-5.19)$ & 24.8 & $1.20(0.92-1.57)$ & 14.2 & $0.60(0.34-1.02)$ \\
\hline Urban zone & 11.7 & 1.00 & 20.6 & 1.00 & 21.7 & 1.00 \\
\hline \multicolumn{7}{|l|}{ Type of injury } \\
\hline Occupational & 23.2 & $1.40(1.01-1.97)$ & 95.6 & $1.11(1.07-1.15)$ & 94.7 & $1.09(1.04-1.14)$ \\
\hline Commuting & 16.6 & 1.00 & 86.4 & 1.00 & 87.1 & 1.00 \\
\hline \multicolumn{7}{|l|}{ Care } \\
\hline Inpatient & 22.0 & $0.97(0.80-1.17)$ & 49.3 & $1.00(0.86-1.16)$ & 53.1 & $1.08(0.90-1.30)$ \\
\hline Other & 22.8 & 1.00 & 49.3 & 1.00 & 49.0 & 1.00 \\
\hline \multicolumn{7}{|l|}{ Outcome } \\
\hline Severe & 22.2 & $0.96(0.78-1.17)$ & 40.7 & $1.88(1.42-2.5)$ & 39.2 & $1.61(1.13-2.27)$ \\
\hline Full recovery & 23.1 & 1.00 & 21.7 & 1.00 & 24.3 & 1.00 \\
\hline
\end{tabular}

wood processing, women are exposed to many unhealthy work conditions. Jakobi ${ }^{17}$ studied the benefits of occupational illness compensation given to beef and seafood workers and found that sometimes women were the main recipients. Activities related to wood processing usually occur in small municipalities, often the main municipal source of labor and economic activity, encouraging women to compete for the few job opportunities and salaries. Pignati and Machado ${ }^{18}$ affirmed that the wood processing phase uses other workers who work indiscriminately in warehouses (sawmills, laminating companies, wood processing companies, and plywood manufacturers) without the necessary personal protective equipment, manipulating old/obsolete, nonautomatic, inefficient machinery brought from other regions where workers have already removed the industrial grade lumber.

The proportion of injuries in plant and animal husbandry workers aged less than 18 years is smaller than in adults. This situation may be related to the public policies and movements against child labor in Brazil and to the employment of minors in administrative positions, which offer a lower risk of occupational injuries. However, in the forestry/wood industry sector, there was no difference in the occupational injuries proportions between the two age groups, indicating that youth are equally exposed to risk. Minors in these environments work more, which is not in compliance with the Principle of Integral Protection $^{19}$, a required presupposition for the understanding of the Child and Adolescent Law in Brazil. Moreover, similar to the higher risks of exposure in women, this sector is often cited as a source of occupational injuries in adolescents.

With regard to education level, one-third of all occupational injuries occurred in illiterate plant husbandry workers, a proportion 1.56 times greater than of injured literate plant husbandry workers. Despite the population being better informed about child labor and compliance with the Child and Adolescent Statute, the sugarcane agribusiness, which employs workers with low qualification, holds the most severe occupational injuries.
Silva and Queiroz ${ }^{20}$ stated that the introduction of mechanical harvesters and high-technology agricultural machinery not only reduces the labor demand, but also introduces into the business workers with another profile, so minors and workers with lower qualifications are left with the most unhealthy and dangerous jobs. This difference was not observed in the other production sectors (animal husbandry and forestry/wood industry), suggesting that opportunities may be more evenly spread, that there may be more inspection by labor agencies, or even that employers may be more encouraged to provide young apprentices with less unhealthy jobs.

This entire situation represents a social and health inequity that challenges the Brazilian Constitution, which prohibits minor labor in dangerous activities. The occurrence of severe occupational injuries in minors working in these three agribusiness sectors of Mato Grosso also denotes a violation of essential rights, as exposure to pesticides and other technical components of the plant husbandry sector and jobs in the production chains of animal husbandry and forestry/wood industry are among the worst kinds of child labor ${ }^{21}$.

In plant husbandry, fewer white individuals suffered occupational injuries than non-white individuals, a finding corroborated by Fehlbert et al. ${ }^{16}$. However, this finding must be interpreted with caution. With the high number of Caucasian owners in the plant and animal husbandry sectors of Mato Grosso, a possible explanation would be a greater proportion of non-whites working the unhealthiest jobs available in these two production sectors. Numerous workers from states with a higher proportion of non-whites have migrated to Mato Grosso to meet the labor demand in these sectors. On the other hand, although the forestry/wood industry sector has lower employee turnover, a more stable population, and a high incidence of occupational injuries, no association was found between ethnicity and risk of occupational injuries. 
Like minors in plant husbandry, the proportion of injured rural plant husbandry workers was higher than of urban workers. In this sense, most agricultural activities occur in rural areas, contrary to animal husbandry, where meat processing occurs in slaughterhouses and meat-processing plants, mostly located in urban areas. The same happens in the forestry/wood industry sector: wood processing occurs in the urban areas of small cities in Mato Grosso's Amazon rainforest region.

All agribusiness sectors had a higher proportion of occupational injuries than commuting accidents. A probable explanation is that most jobs in these sectors are not located in big cities, where motorcycles became a great risk factor for commuting accidents. Road accidents are a great public health problem in Brazil with high morbidity and mortality rates. Brazil prioritizes roads over other transportation routes, and workers are the greatest victims ${ }^{22}$.

Considering that a full recovery is the desired outcome and comparing full recovery with the other outcomes (some type of disability or death), both the animal husbandry and forestry/wood industry sectors are great sources of worker morbidity and mortality. Vasconcellos et al. ${ }^{23}$ studied occupational injuries in the meat processing plants of Mato Grosso from 2000 to 2005 and found that $95.8 \%$ of the injuries required a leave of absence, indicating their severity. Likewise, Ultramari et al. ${ }^{9}$ affirm that the rudimentary nature of forestry-related jobs lead to poor work conditions, low wages, horrible sanitary and safety conditions, and higher likelihood of occurrence of more severe occupational injuries.

\section{FINAL CONSIDERATIONS}

The results of this study indicate that the most serious accidents in agriculture occur to men, of legal age, with low education, non-white skin color and living in the countryside. The outcomes were more severe in the livestock sector than in other productive sectors and also occur more frequently among the oldest workers. Among workers in the timber sector, accidents between minors were proportionally similar to those of legal age and with more severe outcomes than among the evaluated sectors.

Despite the limitations of the health databases used for data collection, this article shows the important repercussions of the agribusiness production chains on the epidemiological profile of the worker's health status. Severe occupational injuries in Brazil's and Mato Grosso's agribusiness are priority issues that the State and civil society must face to improve labor and life conditions. Therefore, this study helps to show that although injuries are often considered personal problems caused by inattentiveness and lack of safety, in reality injuries are closely related to the agribusiness production chains. Therefore, workers' health surveillance should be improved in an intersectoral and participatory manner to enable analyses of the social, technical, and environmental characteristics of the pertinent work processes in order to change them, especially considering that severe occupational injuries have different degrees of social, psychological, financial, and family consequences.

Increasing the occupational injury notification processes, and using this epidemiological information available at SINAN to formulate programs and elect priorities for group surveillance interventions in production chains are key elements for the state of Mato Grosso. This process certainly helps to advance the understanding of rural, forest, urban, and riverine population exposure to environmental and occupational hazards and to implement the National Worker Health Policy in the Amazon region.

\section{ACKNOWLEDGEMENTS}

The authors would like to express their sincere thanks to Dr Gisele Moi (UNIVAG- University Center) for his help in the translation of this paper.

\section{REFERENCES}

1. Instituto Brasileiro de Geografia e Estatística. Trabalho e rendimento. Rio de Janeiro: IBGE; 2012

2. Durigan G. Cerrado: o trade-off entre a conservação e o desenvolvimento. Parcerias Estratégicas. 2012;15(31):243-51.

3. Pignati WA, Machado JMH. O Agronegócio e seus impactos na saúde dos trabalhadores e da população do estado de Mato Grosso. In: Gomez CM, Machado JMH, Pena PGL, organizadores. Saúde do trabalhador na sociedade Brasileira contemporânea. Rio de Janeiro: Editora FIOCRUZ; 2011. 245 p.

4. Faria NMX, Fassa AG, Facchini LA. Intoxicação por agrotóxicos no Brasil: os sistemas oficiais de informação e desafios para a realização de estudos epidemiológicos. Cien Saude Colet. 2007;12(1):25-38. PMid:17680056. http://dx.doi.org/10.1590/S1413-81232007000100008.
5. Silva MJ, Sato MT. Territórios em tensão: o mapeamento dos conflitos socioambientais do Estado de Mato Grosso - Brasil. Ambient Soc. 2012;15(1):1-22. http://dx.doi.org/10.1590/S1414-753X2012000100002.

6. Rigotto RM. Saúde Ambiental \& Saúde dos Trabalhadores: uma aproximação promissora entre o Verde e o Vermelho. Rev Bras Epidemiol. 2003;6(4):388404. http://dx.doi.org/10.1590/S1415-790X2003000400013.

7. Câmara VM, Tambellini AT, Castro HA, Waissmann W. Saúde ambiental e saúde do trabalhador. Epidemiologia das relações entre a produção, o ambiente e a saúde. In: Rouquayrol MZ, Almeida Fo N, organizadores. Epidemiologia e saúde. 6. ed. Rio de Janeiro: Medsi; 2003. p. 496-7.

8. Pignati WA, Machado JMH, Cabral JF. Acidente rural ampliado: o caso das "chuvas" de agrotóxicos sobre a cidade de Lucas do Rio Verde - MT. Rev C S Col. 2007;12:105-14. 
9. Ultramari AV, Silva AMC, Pignati WA. Ambiente de trabalho: influência da produção florestal sobre os acidentes do trabalho no Estado de Mato Grosso. Cad Saude Colet. 2012;20(1):25-31.

10. Brasil. Ministério da Saúde. Secretaria de Atenção à Saúde. Departamento de Ações Programáticas Estratégicas. Notificação de acidentes do trabalho fatais, graves e com crianças e adolescentes. Brasília: Ministério da Saúde; 2006.

11. Brito LSF. Sistema de informações de agravos de notificação - Sinan. In: Anais do Seminário de Vigilância Epidemiológica; 1992 dez. 1-14; Brasília, BR. Brasília: Ministério da Saúde; 1993. p. 145-146.

12. Instituto Brasileiro de Geografia e Estatística. Manual de orientação da codificação da CNAE subclasses [Internet]. Rio de Janeiro: IBGE; 2011 [cited 2015 Jun 18]. Available from: http://www.ibge.gov.br/concla/ http:// subcomissaocnae.fazenda.pr.gov.br

13. Batalha MO. As cadeias de produção agroindustriais: uma perspectiva para o estudo das inovações tecnológicas. Revista de Administração. 1995;30(4):4350 .

14. Instituto Brasileiro de Geografia e Estatística. Estimativas populacionais para os municípios brasileiros [Internet]. Rio de Janeiro: IBGE; 2015 [cited 2015 Jun 18]. Available from: http://www.ibge.gov.br/home/estatistica/populacao/ estimativa2014/default.shtm

15. Leão LHC, Vasconcellos LCF. Cadeias produtivas e a vigilância em saúde, trabalho e ambiente. Saúde Soc. 2015;24(4):1232-1242.

16. Fehlberg MF, Santos I, Tomasi E. Prevalência e fatores associados a acidentes de trabalho em zona rural. Rev Saude Publica. 2001;35(3):269-75. PMid:11486150. http://dx.doi.org/10.1590/S0034-89102001000300009.

17. Jakobi HR, Barbosa-Branco A, Bueno LF, Ferreira RG, Camargo LM. Benefícios auxílio-doença concedidos aos trabalhadores empregados no ramo de carne e pescado no Brasil em 2008. Cad Saude Publica. 2015;31(1):194207. PMid:25715303. http://dx.doi.org/10.1590/0102-311X00087213.

18. Pignati WA, Machado JMH. Riscos e agravos à saúde e à vida dos trabalhadores das indústrias madeireiras de Mato Grosso. Cien Saude Colet. 2005;10(4):961-73. http://dx.doi.org/10.1590/S1413-81232005000400019.

19. Vilas-Bôas RM. A doutrina da proteção integral e os Princípios Norteadores do Direito da Infância e Juventude. Âmbito Jurídico, 2011;14(94):1-4.

20. Silva Fo LA, Queiroz SN. Por dentro da caixa verde: avaliação empírica do emprego formal agropecuário no centro-oeste - 2000/2008. In: Anais do $48^{\circ}$ encontro Nacional da SOBER; 2010 Jul; Campo Grande, BR. Brasília: Sociedade Brasileira de Economia Administração e Sociologia Rural; 2010. p. 1-19.

21. Brasil. Decreto n. 6.481, de 12 de junho de 2008. Regulamenta os artigos $3^{\circ}$, alínea "d", e $4^{\circ}$ da Convenção 182 da Organização Internacional do Trabalho (OIT) que trata da proibição das piores formas de trabalho infantil e ação imediata para sua eliminação. Diário Oficial da União, Brasília, 13 de junho de 2008.

22. Silva DW, Andrade SM, Soares DA, Soares DF, Mathias TA. Perfil do trabalho e acidentes de trânsito entre motociclistas de entregas em dois municípios de médio porte do Estado do Paraná, Brasil. Cad Saude Publica. 2008;24(11):2643-52. PMid:19009144. http://dx.doi.org/10.1590/S0102$311 \mathrm{X} 2008001100019$.

23. Vasconcellos MC, Pignatti MG, Pignati WA. Emprego e acidentes de trabalho na indústria frigorífica em áreas de expansão do agronegócio, Mato Grosso, Brasil. Saúde e Sociedade. 2009;18(4):662-72. http://dx.doi. org/10.1590/S0104-12902009000400010.

Received on: July 02,2015 Accepted on: Dec. 04, 2015 